\title{
UPAYA MENINGKATKAN KOMPETENSI PEDAGOGIK GURU SDN 1 PASAR BANGGI DALAM MENINGKATKAN MOTIVASI BELAJAR PESERTA DIDIK DI SEMESTER I TAHUN PELAJARAN 2018/2019 MELALUI SUPERVISI AKADEMIK TEKNIK KUNJUNGAN KELAS
}

\author{
Maria Aris Wijayanti \\ SDN 1 Pasar Banggi, Kec. Rembang, Kab. Rembang \\ e-mail: aris_mw@yahoo.com
}

\begin{abstract}
The purposes of this reasearch are 1) describing the efforts of increasing the elementary school 1 Pasar Banggi teachers pedagogic competence in order to increase the students learning motivation at the first semester of 2018/2019 academic year by class visitation technique of academic supervision and 2) analysing the increase of increasing the elementary school 1 Pasar Banggi teachers pedagogic competence in order to increase the students learning motivation at the first semester of 2018/2019 academic year by class visitation technique of academic supervision. The type of this research is School Action Research (SAR). The action of this research is class visitation. The place of this research is the elementary school 1 Pasar Banggi, Subdistrict of Rembang, Regency of Rembang. The time of this research is the early first semester of 2018/2019 academic year. The subjects of this research are the class teachers (CT) and the subject teachers (ST) in the elementary school 1 Pasar Banggi, Subdistrict of Rembang, Regency of Rembang, consist of six CT and three ST. The technique of collecting data is using nontest technique. The tools of collecting data are using the sheets of observation and documentation. The data of this research is including teachers pedagogic competence in order to increase the students learning motivation. The data of this research are qualitative and quantitative. The technique of analizing data is decriptive comparation. The procedure of this research is using Cycle Model, consist of four steps: planning, action, observation and reflection. The results of this research are 1) the efforts of increasing the elementary school 1 Pasar Banggi teachers pedagogic competence in order to increase the students learning motivation at the first semester of 2018/2019 academic year by class visitation technique of academic supervision are focussing on the coaching, 2) the efforts of increasing the elementary school 1 Pasar Banggi teachers pedagogic competence in order to increase the students learning motivation at the first semester of 2018/2019 academic year by class visitation technique of academic supervision are individually and participative and 3) the elementary school 1 Pasar Banggi teachers pedagogic competence in order to increase the students learning motivation at the first semester of 2018/2019 academic year by class visitation technique of academic supervision increased and included very high (A) category.
\end{abstract}

Key words: Pedagogic, Teacher, Learning Motivation, Academic Supervision

Tujuan penelitian adalah 1) mendeskripsikan upaya meningkatkan kompetensi pedagogik guru SDN 1 Pasar Banggi dalam meningkatkan motivasi belajar peserta didik di Semester I Tahun Pelajaran 2018/2019 melalui supervisi akademik teknik kunjungan kelas dan 2) menganalisis peningkatan kompetensi pedagogik guru SDN 1 Pasar Banggi dalam meningkatkan motivasi belajar peserta didik di Semester I Tahun Pelajaran 2018/2019 melalui supervisi akademik teknik kunjungan kelas. Jenis penelitian ini adalah Penelitian Tindakan Sekolah (PTS). Tindakan dalam penelitian ini adalah kunjungan kelas. Tempat penelitian di SDN 1 Pasar Banggi, Kecamatan Rembang, Kabupaten Rembang. Waktu penelitian pada awal Semester I Tahun Pelajaran 2018/2019. Subjek penelitian adalah Guru Kelas (GK) dan Guru Pelajaran (GP) di SDN 1 Pasar Banggi, Kecamatan Rembang, Kabupaten Rembang yang terdiri dari enam GK dan tiga GP. Teknik pengumpulan data penelitian ini dengan teknik nontes. 
Sedangkan alat pengumpulan data penelitian ini dengan lembar pengamatan dan dokumentasi. Data penelitian ini meliputi kompetensi pedagogik guru dalam meningkatkan motivasi belajar peserta didik. Data penelitian bersifat kualitatif dan kuantitatif. Teknik analisis data penelitian ini adalah deskriptif komparatif. Prosedur penelitian ini menggunakan Model Siklus yang terdiri dari empat tahap, yaitu perencanaan, tindakan, pengamatan dan refleksi. Hasil penelitian ini adalah 1) Upaya meningkatkan kompetensi pedagogik guru SDN 1 Pasar Banggi dalam meningkatkan motivasi belajar peserta didik di Semester I Tahun Pelajaran 2018/2019 melalui supervisi akademik teknik kunjungan kelas dengan pembinaan yang terfokus, 2) Upaya meningkatkan kompetensi pedagogik guru SDN 1 Pasar Banggi dalam meningkatkan motivasi belajar peserta didik di Semester I Tahun Pelajaran 2018/2019 melalui supervisi akademik teknik kunjungan kelas secara individual maupun secara partisipatif dan 3) Kompetensi pedagogik guru SDN 1 Pasar Banggi dalam meningkatkan motivasi belajar peserta didik di Semester I Tahun Pelajaran 2018/2019 melalui supervisi akademik teknik kunjungan kelas meningkat dan termasuk kategori sangat tinggi (A).

Kata Kunci: Pedagogik, Guru, Motivasi Belajar, Supervisi Akademik

\section{PENDAHULUAN}

Dalam Pasal 10 Undang-Undang Nomor 14 Tahun 2005 tentang Guru dan Dosen dijelaskan bahwa kompetensi guru meliputi kompetensi pedagogik, kompetensi kepdibadian, kompetensi sosial dan kompetensi professional yang diperoleh melalui pendidikan profesi. Lebih lanjut, dalam Peraturan Menteri Pendidikan Nasional (Permendiknas) Nomor 16 Tahun 2007 tentang Standar Kualifikasi Akademik dan Kompetensi Guru dijelaskan bahwa kompetensi guru dikembangkan secara utuh dan terintegrasi dalam kinerja guru.

Sesuai dengan Permendiknas Nomor 16 Tahun 2007 tentang Standar Kualifikasi Akademik dan Kompetensi Guru, salah satu kompetensi pedagogik Guru Kelas SD/MI, juga termasuk Guru Pelajaran (GP), adalah menguasai karakteristik peserta didik dari aspek fisik, moral, sosial, kultural, emosional dan intelektual. Kaitannya dengan karakteristik tersebut, motivasi belajar peserta didik merupakan salah satu aspek yang menjadi perhatian guru. Dengan demikian, kompetensi pedagogik guru tidak sekedar mencakup teori belajar dan pembelajaran maupun pengembangan kuriklulum dan materi semata, tetapi juga mencakup penguasaan karakteristik peserta didik. Dalam hal ini adalah motivasi belajar peserta didik.

SDN 1 Pasar Banggi merupakan salah sekolah yang terletak di sebelah timur dari Kecamatan Rembang, Kabupaten Rembang dan berdekatan dengan beberapa sekolah sederajat lainnya, yaitu SDN 2 Pasar Banggi dan SDN Tritunggal. SDN 1 Pasar Banggi terletak di pemukiman yang berdekatan dengan pantai utara Pulau Jawa. Sesuai keadaan geografis tersebut, karakteristik peserta didik dalam belajar kurang ideal. Kebanyakan peserta didik hanya mengikuti pembelajaran apa adanya, sambil lalu, mengerjakan tugas semampunya dan aktivitas belajar yang kurang aktif. Hal tersebut juga berkaitan dengan kompetensi pedagogik guru yang masih rendah dalam meningkatkan motivasi belajar peserta didik. Sesuai dengan hasil kunjungan kelas pada Kondisi Awal, kompetensi pedagogik guru dalam meningkatkan motivasi belajar peserta didik dengan persentase rata-rata sebesar $26,98 \%$ yang termasuk kategori rendah (D).

Kompetensi pedagogik guru dalam meningkatkan motivasi belajar peserta didik meliputi: 1) peserta didik berminat mengikuti pembelajaran dengan persentase sebesar 44,44\% yang termasuk kategori sedang (C), 2) peserta didik dengan pemahaman konsep yang kuat dengan persentase sebesar 22,22\% yang termasuk kategori rendah (D), 3) peserta didik mengerjakan tugas dengan benar dengan persentase sebesar 22,22\% yang termasuk kategori rendah (D), 4) peserta didik mendapat kesempatan unjuk kerja dengan persentase sebesar $33,33 \%$ yang termasuk kategori rendah (D), 5) pembelajaran dengan kompetisi dengan persentase sebesar $11,11 \%$ yang termasuk kategori sangat rendah (E), 6) pembelajaran dengan kerja sama dengan 
persentase sebesar $11,11 \%$ yang termasuk kategori sangat rendah $(E), 7)$ pujian kepada peserta didik dengan persentase sebesar $44,44 \%$ yang termasuk kategori sedang (C). Hanya satu orang guru $(11,11 \%)$ dengan kompetensi pedagogik guru meningkatkan motivasi belajar peserta didik yang termasuk sangat tinggi (A). Sedangkan tiga guru lainnya $(33,33 \%)$ termasuk kategori sedang (C), satu guru lainnya $(11,11 \%)$ termasuk kategori rendah (D) dan empat guru lainnya $(44,44 \%)$ termasuk kategori sangat rendah (E).

Kompetensi pedagogik guru dalam meningkatkan motivasi belajar peserta didik yang termasuk kategori rendah (D) ini karena guru hanya fokus dengan pembelajaran, sehingga mengabaikan penguasaan karakteristik peserta didik. Padahal motivasi dan belajar adalah dua hal yang saling berkaitan dan tidak terpisahkan. Oleh karena itu, guru perlu meningkatkan motivasi belajar peserta didik.

Berdasarkan latar belakang masalah tersebut, penulis sebagai Kepala SDN 1 Pasar Banggi melakukan tindakan untuk meningkatkan kompetensi pedagogik guru dalam meningkatkan motivasi belajar peserta didik melalui supervisi akademik teknik kunjungan kelas. Dalam supervisi akademik tersebut, penulis melakukan pembinaan tentang upaya meningkatkan motivasi belajar peserta didik yang ditindaklanjuti dengan penugasan. Kemudian, penulis melakukan kunjungan kelas untuk menentukan kompetensi pedagogik. Sesuai dengan tindakan tersebut diharapkan kompetensi pedagogik guru dalam meningkatkan motivasi belajar peserta didik meningkat.

\section{METODE PENELITIAN}

Penelitian ini termasuk dalam jenis Penelitian Tindakan Sekolah (PTS). Penulis merupakan Kepala SDN 1 Pasar Banggi, Kecamatan Rembang, Kabupaten Rembang. Tindakan dalam penelitian ini adalah kunjungan kelas. Dalam kunjungan kelas tersebut, penulis menganalisis kompetensi pedagogik guru dalam meningkatkan motivasi belajar peserta didik.

Tempat penelitian di SDN 1 Pasar Banggi, Kecamatan Rembang, Kabupaten
Rembang. Tempat penelitian beralamat di Desa Pasar Banggi, Kecamatan Rembang, Kabupaten Rembang. Tempat penelitian berdekatan dengan SDN 2 Pasar Banggi dan SDN Tritunggal. Waktu penelitian pada awal Semester I Tahun Pelajaran 2018/2019.

Subjek penelitian adalah Guru Kelas (GK) dan Guru Pelajaran (GP) di SDN 1 Pasar Banggi, Kecamatan Rembang, Kabupaten Rembang yang terdiri dari enam GK dan tiga GP. GK III juga mengampu sebagai GP PJOK Kelas III.

Teknik pengumpulan data penelitian ini dengan teknik nontes. Sedangkan alat pengumpulan data penelitian ini dengan lembar pengamatan dan dokumentasi. Data penelitian bersifat kualitatif dan kuantitatif. Teknik analisis data penelitian ini adalah deskriptif komparatif. Prosedur penelitian ini menggunakan Model Siklus yang terdiri dari empat tahap, yaitu perencanaan, tindakan, pengamatan dan refleksi. Penulis menyusun prosedur penelitian selama dua siklus.

\section{HASIL PENELITIAN DAN \\ PEMBAHASAN \\ Deskripsi Siklus I}

Pada Siklus I, subjek penelitian melakukan penilaian diri sendiri sesuai dengan form yang diberikan setelah pembelajaran selesai. Subjek penelitian tidak mengetahui indikator yang termasuk dalam form penilaian diri sendiri. Subjek penelitian hanya fokus pada pengelolaan pembelajaran yang berkelanjutan secara proporsional, khususnya dalam membuka dan menutup pembelajaran.

Supervisi akademik teknik kunjungan kelas pada Siklus I berlangsung secara individual, dimana penulis melakukan kunjungan kelas seorang diri. Jadwal kunjungan kelas terstruktur dan sistematis, sehingga tidak bersamaan antara subjek penelitian yang satu dengan yang lain. Sesuai dengan hasil pembinaan, subjek penelitian meningkatkan motivasi belajar peserta didik sesuai dengan tema dan materi berikutnya menurut jadwal kunjungan kelas. Subjek penelitian mengetahui keterkaitan antara motivasi dengan belajar dan memahami indikator-indikator yang berkaitan dengan 
meningkatkan motivasi belajar peserta didik dalam pembelajaran.

Pada Siklus I, kompetensi pedagogik guru dalam meningkatkan motivasi belajar peserta didik dengan persentase sebesar $61,9 \%$ yang termasuk kategori tinggi (B). Peningkatan kompetensi pedagogik tersebut memenuhi indikator keberhasilan tindakan.

Pada Siklus I, kompetensi pedagogik guru dalam meningkatkan motivasi belajar peserta didik minimal termasuk kategori tinggi (B) sebanyak empat subjek penelitian atau $44,44 \%$, terdiri dari satu subjek penelitian atau $11,11 \%$ termasuk kategori sangat tinggi (A) dan tiga subjek penelitian atau $33,33 \%$ termasuk kategori tinggi (B). Sedangkan lima subjek penelitian lainnya atau $55,55 \%$ termasuk kategori sedang (C). Kompetensi pedagogik tersebut belum memenuhi indikator keberhasilan tindakan.

\section{Deskripsi Siklus II}

Supervisi akademik teknik kunjungan kelas pada Siklus II berlangsung secara partisipatif, dimana penulis melakukan kunjungan kelas bersama dengan subjek penelitian yang berminat. Jadwal kunjungan kelas berkelanjutan, sehingga subjek penelitian berkesempatan berpatisipasi. Sesuai dengan hasil pembinaan, subjek penelitian menggunakan metode belajar dan media pembelajaran sesuai dengan tema dan materi berikutnya. Selain itu, subjek penelitian juga menggunakan pembelajaran dalam kelompok dengan belajar bersama dan bekerja sama, hingga kompetisi antar kelompok.

Pada Siklus II, kompetensi pedagogik guru dalam meningkatkan motivasi belajar peserta didik dengan persentase sebesar $87,3 \%$ yang termasuk kategori sangat tinggi (A). Peningkatan kompetensi pedagogik tersebut memenuhi indikator keberhasilan tindakan.

Pada Siklus II, kompetensi pedagogik guru dalam meningkatkan motivasi belajar peserta didik minimal termasuk kategori sangat tinggi (A) sebanyak sembilan subjek penelitian atau $100 \%$, terdiri dari delapan subjek penelitian atau $88,88 \%$ termasuk kategori sangat tinggi (A) dan satu subjek penelitian atau $11,11 \%$ termasuk kategori tinggi (B). Kompetensi pedagogik tersebut memenuhi indikator keberhasilan tindakan.

\section{Pembahasan}

Kompetensi pedagogik guru SDN 1 Pasar Banggi dalam meningkatkan motivasi belajar peserta didik pada Kondisi Awal dengan persentase rata-rata hanya sebesar $26,98 \%$ yang termasuk kategori rendah (D). Oleh karena itu, penulis melakukan supervisi akademik teknik kunjungan kelas.

Supervisi akademik teknik kunjungan kelas diawali dengan pembinaan tentang upaya meningkatkan motivasi belajar peserta didik yang ditindaklanjuti dengan penugasan. Pembinaan dilaksanakan pada hari sabtu. Sedangkan kunjungan kelas dilaksanakan pada hari senin sampai hari jumat pada minggu berikutnya. Kunjungan kelas dengan menganalisis kompetensi pedagogik guru dalam meningkatkan motivasi belajar peserta didik. Kunjungan kelas terstruktur dan sistematis, sehingga tidak bersamaan antara subjek penelitian yang satu dengan yang lain.

Supervisi akademik teknik kunjungan kelas pada Siklus I berlangsung secara individual, dimana penulis melakukan kunjungan kelas seorang diri. Kompetensi pedagogik guru dalam meningkatkan motivasi belajar peserta didik dengan persentase sebesar $61,9 \%$ yang termasuk kategori tinggi (B). Kompetensi pedagogik guru dalam meningkatkan motivasi belajar peserta didik minimal termasuk kategori tinggi sebanyak empat subjek penelitian atau $44,44 \%$, terdiri dari satu subjek penelitian atau $11,11 \%$ termasuk kategori sangat tinggi (A) dan tiga subjek penelitian atau 33,33\% termasuk kategori tinggi (B). Sedangkan lima subjek penelitian lainnya atau $55,55 \%$ termasuk kategori sedang (C).

Peningkatan kompetensi pedagogik guru dalam meningkatkan motivasi belajar peserta didik pada Siklus I sesuai dengan pembinaan kepada subjek penelitian tentang meningkatkan motivasi belajar peserta didik. Pembelajaran tidak hanya sekedar menyampaikan materi, tetapi juga memotivasi peserta didik untuk belajar. Motivasi dan belajar adalah dua hal yang saling berkaitan dan tidak terpisahkan. 
Supervisi akademik teknik kunjungan kelas pada Siklus II berlangsung secara partisipatif, dimana penulis melakukan kunjungan kelas bersama dengan subjek penelitian yang berminat. Kompetensi pedagogik guru dalam meningkatkan motivasi belajar peserta didik dengan persentase sebesar $87,3 \%$ yang termasuk kategori sangat tinggi (A). Kompetensi pedagogik guru dalam meningkatkan motivasi belajar peserta didik minimal termasuk kategori sangat tinggi (A) sebanyak sembilan subjek penelitian atau $100 \%$, terdiri dari delapan subjek penelitian atau $88,88 \%$ termasuk kategori sangat tinggi (A) dan satu subjek penelitian atau $11,11 \%$ termasuk kategori tinggi (B).

Peningkatan kompetensi pedagogik guru dalam meningkatkan motivasi belajar peserta didik pada Siklus II sesuai dengan pembinaan kepada subjek penelitian tentang teknik dan prosedur pembelajaran yang bervariasi (kerja sama dan kompetisi) menggunakan metode belajar dan media pembelajaran. Pembelajaran tidak hanya berlangsung secara klasikal, tetapi juga menggunakan metode belajar dan media pembelajaran. Pembelajaran yang bervariasi meningkatkan motivasi belajar peserta didik, sehingga tidak bosan maupun jenuh. Begitu juga dengan pembelajaran dalam kelompok, tidak hanya berkumpul dalam kelompok, tetapi juga belajar bersama dan bekerja sama.

Kompetensi pedagogik guru dalam meningkatkan motivasi belajar peserta didik meningkat. Hasil analisis kompetensi pedagogik guru dalam meningkatkan motivasi belajar peserta didik pada Siklus I dan Siklus II sesuai dengan grafik dan tabel sebagai berikut:

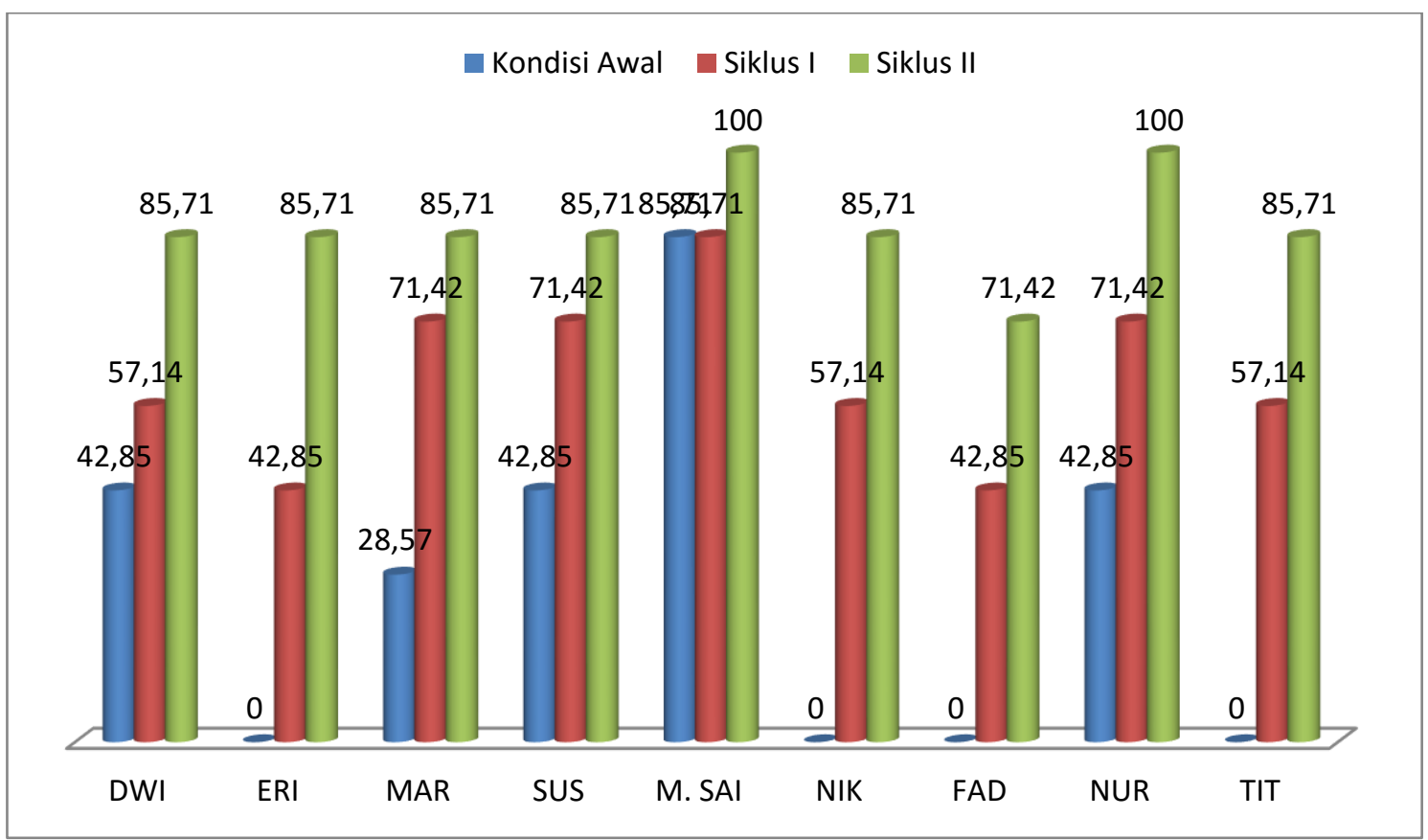

Grafik 1. Analisis kompetensi pedagogik guru dalam meningkatkan motivasi belajar peserta didik pada Kondisi Awal, Siklus I dan Siklus II.

Tabel 4. Analisis kompetensi pedagogik guru dalam meningkatkan motivasi belajar peserta didik pada Siklus I dan Siklus II.

\begin{tabular}{|l|l|l|l|}
\hline No & Aspek Pengamatan & S I & S II \\
\hline 1 & Memperjelas tujuan belajar yang hendak dicapai & $\begin{array}{l}88,88 \\
\text { (A) }\end{array}$ & 100 (A) \\
\hline 2 & $\begin{array}{l}\text { Menggunakan materi yang dikenal peserta didik } \\
\text { sebagai contoh dalam belajar }\end{array}$ & $\begin{array}{l}77,77 \\
\text { (B) }\end{array}$ & $\begin{array}{l}88,88 \\
\text { (A) }\end{array}$ \\
\hline 3 & $\begin{array}{l}\text { Menimbulkan rasa ingin tahu melalui konflik } \\
\text { konseptual }\end{array}$ & $\begin{array}{l}77,77 \\
(\mathrm{~B})\end{array}$ & $\begin{array}{l}88,88 \\
\text { (A) }\end{array}$ \\
\hline
\end{tabular}




\begin{tabular}{|l|l|l|l|}
\hline 4 & Memberikan tugas-tugas yang tidak terlampau sulit & $\begin{array}{l}33,33 \\
(\mathrm{D})\end{array}$ & $\begin{array}{l}66,66 \\
(\mathrm{~B})\end{array}$ \\
\hline 5 & $\begin{array}{l}\text { Memberikan kesempatan kepada peserta didik untuk } \\
\text { memperlihatkan kemampuannya di depan umum }\end{array}$ & $\begin{array}{l}66,66 \\
(\mathrm{~B})\end{array}$ & $\begin{array}{l}77,77 \\
(\mathrm{~B})\end{array}$ \\
\hline 6 & $\begin{array}{l}\text { Menggunakan teknik dan prosedur pembelajaran } \\
\text { yang bervariasi (kerja sama dan kompetisi) }\end{array}$ & $\begin{array}{l}11,11 \\
(\mathrm{E})\end{array}$ & $\begin{array}{l}88,88 \\
(\mathrm{~A})\end{array}$ \\
\hline 7 & Menggunakan pernyataan verbal & $\begin{array}{l}77,77 \\
(\mathrm{~B})\end{array}$ & $100(\mathrm{~A})$ \\
\hline \multicolumn{2}{|l|}{ Persentase/Kategori } & $61,9(\mathrm{~B})$ & $87,3(\mathrm{~A})$ \\
\hline
\end{tabular}

Dalam penelitian ini, penulis sebagai Kepala Sekolah berperan menjadi supervisor yang melakukan supervisi akademik teknik kunjungan kelas. Dalam kunjungan kelas tersebut, penulis mengetahui kompetensi pedagogik subjek penelitian dalam meningkatkan motivasi belajar peserta didik. Sesuai dengan hasil pembinaan dan kunjungan kelas, kompetensi pedagogik subjek penelitian mengalami peningkatan.

Dalam penelitian ini, penulis melakukan supervisi akademik teknik kunjungan kelas dengan pengamatan terhadap pembelajaran yang sedang berlangsung. Pada Siklus I, kunjungan kelas secara individual. Sedangkan pada Siklus II, kunjungan kelas secara partisipatif.

Dalam penelitian ini, penulis melakukan supervisi akademik teknik kunjungan kelas secara bertahap, sehingga berhasil meningkatkan kompetensi pedagogik subjek penelitian dalam meningkatkan motivasi belajar peserta didik. Pada tahap persiapan, penulis menentukan pembinaan pada hari sabtu dan kunjungan kelas pada hari senin sam[ai hari jumat, dimana kunjungan kelas tersebut terstruktur dan sistematis sesuai dengan subjek penelitian tertentu, sehingga tidak bersamaan. Pada tahap pengamatan, penulis menganalisis kesesuaian indikator kompetensi pedagogik subjek penelitian dalam meningkatkan motivasi belajar peserta didik dalam pembelajaran. Pada tahap akhir kunjungan, penulis menyampaikan hasil kunjungan kelas pada pembinaan berikutnya. Pada tahap akhir, penulis menindaklanjuti pembinaan secara fokus pada indikatorindikator yang belum terpenuhi, termasuk menyampaikan hasil kunjungan kelas.

Dalam penelitian ini, kunjungan kelas tanpa menganggu pembelajaran yang sedang berlangsung. Penulis mengamati dan menganalisis kompetensi pedagogik subjek penelitian dalam meningkatkan motivasi belajar peserta didik sesuai dengan indikator dalam lembar pengamatan, sehingga pembelajaran yang sedang berlangsung sama sekali tidak terganggu.

\section{KESIMPULAN}

1. Upaya meningkatkan kompetensi pedagogik guru SDN 1 Pasar Banggi dalam meningkatkan motivasi belajar peserta didik di Semester I Tahun Pelajaran 2018/2019 melalui supervisi akademik teknik kunjungan kelas dengan pembinaan yang terfokus dan kunjungan kelas secara individual maupun secara partisipatif.

2. Kompetensi pedagogik guru SDN 1 Pasar Banggi dalam meningkatkan motivasi belajar peserta didik di Semester I Tahun Pelajaran 2018/2019 melalui supervisi akademik teknik kunjungan kelas meningkat dan termasuk kategori sangat tinggi (A). Pada Kondisi Awal, kompetensi pedagogik dengan persentase rata-rata hanya sebesar 26,98\% yang termasuk kategori rendah (D). Pada Siklus I, kompetensi pedagogik dengan persentase rata-rata sebesar $61,9 \%$ yang termasuk kategori tinggi (B). Pada Siklus II, kompetensi pedagogik dengan persentase rata-rata sebesar $87,3 \%$ yang termasuk kategori sangat tinggi (A).

\section{Saran}

1. Bagi guru supaya memberikan tugas dengan tingkat kesulitan yang bertahap dan jumlah yang proporsional, sehingga motivasi belajar peserta didik semakin meningkat.

2. Bagi peserta didik supaya memperkuat motivasi intrinsik, sehingga motivasi belajar semakin meningkat. 
Bagi sekolah supaya memberikan maupun peserta didik, sehingga motivasi hadiah maupun penghargaan bagi guru ekstrinsik semakin meningkat.

\section{DAFTAR PUSTAKA}

Anonim. 2008. Metode dan Teknik Supervisi. Jakarta: Direktorat Tenaga Kependidikan, Direktorat Jenderal Peningkatan Mutu Pendidik dan Tenaga Kependidikan, Departemen Pendidikan Nasional.

Aqib, Zainal. 2014. Penelitian Tindakan Kelas. Bandung: Yrama Widya.

Hamalik, Oemar. 2001. Psikologi Belajar dan Mengajar. Bandung: Sinar Baru Algesindo.

Masaong, Abdul Kadim. 2013. Supervisi Pembelajaran dan Pengembangan Kapasitas Guru; Memberdayakan Pengawas sebagai Gurunya Guru. Bandung: Alfabeta.

Mulyasa. 2009. Implementasi Kurikulum Tingkat Satuan Pendidikan: Kemandirian Guru dan Kepala Sekolah. Jakarta: Bumi Aksara.

Peraturan Menteri Pendidikan Nasional Nomor 16 Tahun 2007 tentang Standar Kualifikasi Akademik dan Kompetensi Guru.

Peraturan Pemerintah Nomor 74 Tahun 2008 tentang Guru.

Rasyid, Mansur Harun. 2009. Penilaian Hasil Belajar. Bandung: Wacana Prima.

Sardiman. 2011. Interaksi dan Motivasi Belajar Mengajar. Jakarta: Rajawali Press.

Suhardan, Dadang. 2010. Supervisi Profesional. Bandung: Alfabeta.

Suparlan. 2008. Membangun Sekolah Efektif. Yogyakarta: Hikayat.

Uno, Hamzah. 2007. Teori Motivasi dan Pengukurannya: Analisis di Bidang Pendidikan. Jakarta: Bumi Aksara. 